\title{
INFLUENCE OF VACUUM ACTIVATED DIFFUSION CHROMING ON MECHANICAL PROPERTIES OF THE SURFACE OF STEEL 25X1MF
}

\author{
S.G. Rudenkyi, V.I. Zmij, N.F. Kartzev, A.A. Korneev, A.V. Kunchenko, V.V. Kunchenko, \\ Y.V. Kunchenko, V.G. Marinin, V.I. Kovalenko, M.O. Bortnytska, \\ T.P. Ryzhova, and I.A. Lashenko \\ National Science Center "Kharkov Institute of Physics and Tecnology", Kharkiv, Ukraine \\ E-mail: rudenkyi@kipt.kharkov.ua
}

In the work, the surface of samples made of 25X1MF steel was saturated with chromium. For this, the method of vacuum activated diffusion chromium plating was used. In this process, sodium chloride was used as an activator. It was found that vacuum activated diffusion chromium plating of samples made of $25 \mathrm{Kh} 1 \mathrm{MF}$ steel leads to the formation of a surface layer containing from 87 to $97 \mathrm{wt} . \%$ of this element. It was found that an increase in the temperature of the process and its duration leads to an increase in the chromium content on the surface of the samples. The tests showed that in the case of cavitations-erosion effects on the surface of chrome-plated samples of steel $25 \mathrm{X} 1 \mathrm{MF}$ they have higher resistance. With abrasive wear, the resistance of the chrome-plated steel surface is 1.8 to 3 times higher compared to untreated material.

\section{INTRODUCTION}

Steel $25 \mathrm{X} 1 \mathrm{MF}$ is widely used in engineering. With the development of production, there is an increase in requirements for products, in particular, steel $25 \mathrm{X} 1 \mathrm{MF}$. To meet the needs of production, you can try to replace this steel with a more resistant one or to protect its surface by some method. There are many ways to protect the surface of steels, and one of them is the method of vacuum activated diffusion saturation, which allows saturating the surface of metals and carbon materials with a number of elements, such as titanium, chromium, zirconium, hafnium, and others. When used as an activator of sodium chloride, this process is environmentally friendly. Examples of chromium plating of carbon steels are known from the literature [1, 2]. In this case, chromium plating is carried out in a container with a "fusible shutter" (pack cementation process). This process proceeds at atmospheric pressure and an air atmosphere is present in the reaction space. In diffusion saturation by this method, the coating contains interstitial elements, which is the reason for the low quality of the diffusion layer. In addition, in this process, thermodynamically unstable halides are used as an activator, which leads to the formation of harmful gaseous emissions. The process of vacuum activated diffusion chromium plating is carried out at a temperature of $1050 \ldots 1120^{\circ} \mathrm{C}$. Such a high temperature provides strong adhesion of the diffusion layer to the substrate and the formation of a continuous protective layer on the product. The method of activated diffusion saturation allows you to form a uniform protective layer over the entire surface of the product, having a complex shape and holes of small diameter [3, 4]. Chromium plating of steels using sodium chloride vapor as an activator helps to increase their cavitation-erosion and abrasion resistance. But such data are available only for steel grades: Ct. 20, Ct. 3, Ct. 45 and U8 [5-8]. For other steels, data on the effect of chromium plating carried out by the method of vacuum activated saturation in sodium chloride vapors were not found in the literature. The use of other methods of hardening the steel surface, such as boronation, provides an increase in resistance to mechanical wear, but will not always impede cavitationerosion effects. A chromium-based diffusion coating is more ductile than boride, and better resists cyclic damage. Therefore, it is necessary to study the process of vacuum diffusion chromium plating of multicomponent materials in sodium chloride vapors, which allows the formation of a high-quality protective layer on complex alloyed steels. The aim of the work is to study the influence of process parameters of vacuum activated diffusion chromium plating of the $25 \mathrm{X} 1 \mathrm{MF}$ steel surface on its strength characteristics - erosion and cavitation resistance, composition and structure.

\section{MATERIALS AND METHODS RESEARCH}

Round washers with a diameter of $18 \mathrm{~mm}$ and a thickness of $4 \mathrm{~mm}$ were used as samples for chromium plating and subsequent studies. The composition of steel 25X1MF measured by X-ray fluorescence analysis (XRD) before chromium plating was (wt.\%): $\mathrm{V}=0.2$; $\mathrm{Cr}=1.9 ; \mathrm{Fe}=97.3 ; \mathrm{Cu}=0.4$. From the presented measurement results it follows that the method used to measure the composition of the steel does not fully provide information on the composition of the material. The mechanism of the process of vacuum activated chromium plating of steel can be described as follows. Samples are placed in a graphite container containing chromium powder and sodium chloride. The container has an internal diameter of 50-60 mm and a length of 250-300 mm. For saturation, chromium powder with a particle size of 0.1 to $3 \mathrm{~mm}$ was used. This container is placed in a furnace located in a vacuum chamber. The diameter of the vacuum chamber is $500 \mathrm{~mm}$ and its height is $600 \mathrm{~mm}$. Vacuum activated chrome plating was carried out in three plants and therefore their dimensions may slightly differ from the above. To heat the vacuum furnace, an electric power unit with a capacity of about $10 \mathrm{~kW}$ was used. In addition, an electrical voltage was supplied to the unit to power the forevacuum and diffusion pumps, as well as instrumentation. For each installation, these capacities were differ- 
ent, i.e. they ranged from 6 to $10 \mathrm{~kW}$. After that, the chamber is evacuated to a residual gas pressure of less than $1 \cdot 10^{-2} \mathrm{~Pa}$ and the furnace is heated to saturation temperature. Under these conditions, isothermal exposure is performed. In this process, the activator vapor interacts with chromium, which leads to the formation of a gas saturating medium consisting of gaseous chlorides $\mathrm{CrCl}, \mathrm{CrCl} 2, \mathrm{CrCl} 3, \mathrm{CrCl} 4, \mathrm{Cr} 2 \mathrm{Cl} 4$, sodium vapor, and sodium chloride [8]. The ratio of the components in this gaseous medium depends on the temperature and pressure in the reaction space. As follows from the re-

During the entire annealing time, sodium chloride vapors are fed into the container - about $1 \mathrm{~g} / \mathrm{h}$. The annealing temperature was 1070 or $1100{ }^{\circ} \mathrm{C}$, the duration of the process varied in the range from 6 to $12 \mathrm{~h}$. The vacuum activated diffusion chromium plating process in sodium chloride vapors is carried out in a graphite container similar to a Knudsen cell. In its volume creates a uniform pressure and distribution of the gaseous components of the saturating medium. To create an activator flow equal to $1 \mathrm{~g} / \mathrm{h}$, it is necessary to maintain the temperature of sodium chloride at about $800{ }^{\circ} \mathrm{C}$. At this temperature of this compound, its vapor pressure is about $133 \mathrm{~Pa}$. Considering that the pressure in the vacuum chamber does not exceed $0.1 \mathrm{~Pa}$, in the reaction space it should be in the range of $1.33 \ldots 133 \mathrm{~Pa}$.

To study the surface of the samples in order to determine the composition, the Sprut installation (XRA) was used; to study the phase composition, Drone-3.0. The structure of the surface layer was studied using an MMO-1600 optical microscope, and the microhardness of the coating was measured using a PMT-3 device.

\section{RESULTS AND ITS DISCUSSION}

Influence of the process of vacuum activated chromium plating on the roughness of samples made of 25X1MF steel. sults of thermodynamic calculations, with increasing temperature and lowering pressure, the relative content of lower chloride and sodium vapor increases [8]. This gaseous medium interacts with a saturable surface and the formation of a diffusion layer based on chromium occurs on it through reactions $1-4$.

$$
\begin{aligned}
& \mathrm{CrCl}(\mathrm{g})+3 / 4 \mathrm{Me}(\mathrm{s})=3 / 4(\mathrm{MeCr})(\mathrm{s})+1 / 4 \mathrm{CrCl}_{4}(\mathrm{~g}) \\
& \mathrm{CrCl}_{2}(\mathrm{~g})+1 / 2 \mathrm{Me}(\mathrm{s})=1 / 2(\mathrm{MeCr})(\mathrm{s})+1 / 2 \mathrm{CrCl}_{4}(\mathrm{~g}) \\
& \mathrm{CrCl}_{3}(\mathrm{~g})+1 / 4 \mathrm{Me}(\mathrm{s})=1 / 4(\mathrm{MeCr})(\mathrm{s})+3 / 4 \mathrm{CrCl}_{4}(\mathrm{~g}) \\
& \mathrm{Cr}_{2} \mathrm{Cl}_{4}(\mathrm{~g})+\mathrm{Me}(\mathrm{s})=(\mathrm{MeCr})(\mathrm{s})+\mathrm{CrCl}_{4}(\mathrm{~g})
\end{aligned}
$$

Sample No. 5: initial: roughness: direction $\mathrm{x}=0.113 \mu \mathrm{m}, \mathrm{y}=0.088 \mu \mathrm{m}$; after chromium plating at $T=1100{ }^{\circ} \mathrm{C}$ for $12 \mathrm{~h}$; the sample had a roughness: direction $\mathrm{x}=1.12 \mu \mathrm{m}, \mathrm{y}=1.26 \mu \mathrm{m}$.

Sample No. 6: initial: roughness: $\mathrm{x}$ direction $=$ $0.063 \mu \mathrm{m}, \quad \mathrm{y}=0.075 \mu \mathrm{m} ; \quad$ chromium plating at $T=1070{ }^{\circ} \mathrm{C}$ for $8 \mathrm{~h}$; after that, the roughness in the direction $\mathrm{x}=0.45 \mu \mathrm{m}, \mathrm{y}=0.38 \mu \mathrm{m}$.

As follows from the data presented, by measuring the surface topography of samples, chrome plating increases their roughness. As a result of this, it is necessary to carry out studies to optimize the chromium parameters, i.e. select the necessary temperature of chromium plating, the duration of the process and the concentration of activator, the particle size of the chromium powder used in chemical-thermal treatment. Of the presented in table 1 of the data it follows that an increase in the temperature of the process and its duration leads to an increase in the chromium content on the surface of the samples. Its amount is from 87 to $97 \mathrm{wt} \%$. This should help increase the heat resistance of the chrome surface of this steel.

The surface composition of the samples after chromium plating, measured by XRA

Table 1

\begin{tabular}{|c|c|c|c|c|}
\hline $\begin{array}{c}\text { No. } \\
\text { sample }\end{array}$ & $\begin{array}{c}\text { Microhardness } \\
\text { steel surfaces up to } \\
\text { chrome plating } H_{\mu}, \mathrm{kg} / \mathrm{mm}^{2}\end{array}$ & $\begin{array}{c}\text { Temperature } \\
\text { chromium } \\
\text { plating, }{ }^{0} \mathrm{C}\end{array}$ & $\begin{array}{c}\text { Time } \\
\text { chrome } \\
\text { plating, } \mathrm{h}\end{array}$ & $\begin{array}{c}\text { Surface composition } \\
\text { after } \\
\text { chromium, wt.\% }\end{array}$ \\
\hline 1 & 224 & 1100 & 6 & $88,9 \mathrm{Cr}+11,1 \mathrm{Fe}$ \\
\hline 2 & 233 & 1100 & 8 & $92,4 \mathrm{Cr}+7,6 \mathrm{Fe}$ \\
\hline 3 & 224 & 1100 & 10 & $97,1 \mathrm{Cr}+2,9 \mathrm{Fe}$ \\
\hline 4 & 228 & 1100 & 12 & $96,9 \mathrm{Cr}+3,1 \mathrm{Fe}$ \\
\hline 5 & 221 & 1070 & 6 & $87,7 \mathrm{Cr}+12,2 \mathrm{Fe}$ \\
\hline 6 & 233 & 1070 & 8 & $87,1 \mathrm{Cr}+12,9 \mathrm{Fe}$ \\
\hline 7 & 221 & 1070 & 10 & $92,3 \mathrm{Cr}+7,7 \mathrm{Fe}$ \\
\hline
\end{tabular}

\section{THERMODYNAMIC ANALYSIS CHROME PROCESSING PROCESS}

We performed a thermodynamic calculation of possible chemical reactions between the gaseous components of the saturating medium and the carbon present in the steel. The calculation was performed for temperatures of 1070 and $1100{ }^{\circ} \mathrm{C}$, boundary pres sure values - 133 and $1.33 \mathrm{~Pa}$. In the calculation, thermodynamic data from the source were used [9]. The results of this calculation are presented in Table 2. The magnitude of the chemical reaction $\alpha$ is the fraction of the starting materials that have reacted in accordance with the reaction. 
The magnitude of the occurrence of chemical reactions $\alpha$ describing the interaction of chromium chlorides with carbon

\begin{tabular}{|l|l|c|c|c|c|}
\hline \multirow{2}{*}{ No } & \multirow{2}{*}{ Chemical equation } & \multicolumn{3}{|c|}{ Process temperature, $\mathrm{K}$} \\
\cline { 3 - 6 } & & \multicolumn{2}{|c|}{1343} & \multicolumn{2}{c|}{1373} \\
\cline { 3 - 6 } & & \multicolumn{2}{|c|}{ Pressure, Pa } & \multicolumn{2}{c|}{ Pressure, Pa } \\
\cline { 3 - 6 } & & 133 & 1.33 & 133 & 1.33 \\
\hline 1 & $\mathrm{CrCl}(\mathrm{g})+9 / 46 \mathrm{C}(\mathrm{s})=3 / 92 \mathrm{Cr}_{23} \mathrm{C}_{6}(\mathrm{~s})+1 / 4 \mathrm{CrCl}_{4}(\mathrm{~g})$ & 0.998 & 0.94 & 0.998 & 0.94 \\
\hline 2 & $\mathrm{CrCl}(\mathrm{g})+9 / 286 \mathrm{C}(\mathrm{s})=3 / 28 \mathrm{Cr}_{7} \mathrm{C}_{3}(\mathrm{~s})+1 / 4 \mathrm{CrCl}_{4}(\mathrm{~g})$ & 0.892 & 0.997 & 0.997 & 0.895 \\
\hline 3 & $\mathrm{CrCl}(\mathrm{g})+1 / 2 \mathrm{C}(\mathrm{s})=1 / 4 \mathrm{Cr}_{3} \mathrm{C}_{2}(\mathrm{~s})+1 / 4 \mathrm{CrCl}_{4}(\mathrm{~g})$ & 0.999 & 0.95 & 0.997 & 0.95 \\
\hline 4 & $\mathrm{CrCl}_{2}(\mathrm{~g})+3 / 23 \mathrm{C}(\mathrm{s})=1 / 46 \mathrm{Cr}_{23} \mathrm{C}_{6}(\mathrm{~g})+1 / 2 \mathrm{CrCl}_{4}(\mathrm{~g})$ & $6.4 \cdot 10^{-6}$ & $6.4 \cdot 10^{-8}$ & $4.2 \cdot 10^{-6}$ & $4.2 \cdot 10^{-8}$ \\
\hline 5 & $\mathrm{CrCl}_{2}(\mathrm{~g})+3 / 146 \mathrm{C}(\mathrm{s})=1 / 14 \mathrm{Cr}_{7} \mathrm{C}_{3}(\mathrm{~s})+1 / 2 \mathrm{CrCl}_{4}(\mathrm{~g})$ & $5.4 \cdot 10^{-5}$ & $5.4 \cdot 10^{-7}$ & $3.6 \cdot 10^{-5}$ & $3.6 \cdot 10^{-7}$ \\
\hline 6 & $\mathrm{CrCl}_{2}(\mathrm{~g})+1 / 3 \mathrm{C}(\mathrm{s})=1 / 6 \mathrm{Cr}_{3} \mathrm{C}_{2}(\mathrm{~s})+1 / 2 \mathrm{CrCl}_{4}(\mathrm{~g})$ & 0.099 & $1.2 \cdot 10^{-3}$ & 0.14 & $1.8 \cdot 10^{-3}$ \\
\hline 7 & $\mathrm{Cr}_{2} \mathrm{Cl}_{4}(\mathrm{~g})+6 / 23 \mathrm{C}(\mathrm{s})=1 / 23 \mathrm{Cr}_{23} \mathrm{C}_{6}(\mathrm{~s})+\mathrm{CrCl}_{4}(\mathrm{~g})$ & 0.146 & 0.146 & 0.15 & 0.15 \\
\hline 8 & $\mathrm{Cr}_{2} \mathrm{Cl}_{4}(\mathrm{~g})+3 / 7 \mathrm{C}(\mathrm{s})=1 / 7 \mathrm{Cr}_{7} \mathrm{C}_{3}(\mathrm{~s})+\mathrm{CrCl}_{4}(\mathrm{~g})$ & 0.213 & 0.213 & 0.216 & 0.216 \\
\hline 9 & $\mathrm{Cr}_{2} \mathrm{Cl}_{4}(\mathrm{~g})+2 / 3 \mathrm{C}(\mathrm{s})=1 / 3 \mathrm{Cr}_{3} \mathrm{C}_{2}(\mathrm{~s})+\mathrm{CrCl}_{4}(\mathrm{~g})$ & 0.233 & 0.233 & 0.236 & 0.236 \\
\hline 10 & $\mathrm{CrCl}_{3}(\mathrm{~g})+3 / 46 \mathrm{C}(\mathrm{s})=1 / 92 \mathrm{Cr}_{23} \mathrm{C}_{6}(\mathrm{~s})+3 / 4 \mathrm{CrCl}_{4}(\mathrm{~g})$ & $4 \cdot 10^{-3}$ & $8.6 \cdot 10^{-4}$ & $3.5 \cdot 10^{-3}$ & $7.6 \cdot 10^{-4}$ \\
\hline 11 & $\mathrm{CrCl}_{3}(\mathrm{~g})+3 / 28 \mathrm{C}(\mathrm{s})=1 / 28 \mathrm{Cr}_{7} \mathrm{C}_{3}(\mathrm{~s})+3 / 4 \mathrm{CrCl}_{4}(\mathrm{~g})$ & $4.6 \cdot 10^{-3}$ & $1 \cdot 10^{-3}$ & $4 \cdot 10^{-3}$ & $8.8 \cdot 10^{-4}$ \\
\hline 12 & $\mathrm{CrCl}_{3}(\mathrm{~g})+1 / 6 \mathrm{C}(\mathrm{s})=1 / 12 \mathrm{Cr}_{23} \mathrm{C}_{6}(\mathrm{~s})+3 / 4 \mathrm{CrCl}_{4}(\mathrm{~g})$ & $4.8 \cdot 10^{-3}$ & $1 \cdot 10^{-3}$ & $4.2 \cdot 10^{-3}$ & $9.1 \cdot 10^{-4}$ \\
\hline
\end{tabular}

Of the presented in table 2 of the data it follows that the main reactions leading to the formation of carbide are 1-3 and 6-9. In accordance with these reactions, three carbides can form: $\mathrm{Cr}_{23} \mathrm{C}_{6}, \mathrm{Cr}_{7} \mathrm{C}_{3}, \mathrm{Cr}_{3} \mathrm{C}_{2}$. From the results of $\mathrm{X}$-ray diffraction analysis it follows that the formation of carbide $\mathrm{Cr}_{23} \mathrm{C}_{6}$ containing the least amount of carbon occurs. This is due to the low carbon content in this steel grade.

The carbon present in the steel is concentrated in the surface layer and forms a carbide layer of composition $\mathrm{Cr}_{23} \mathrm{C}_{6}$. It can also be concluded that the main substances - carriers of chromium are gaseous compounds $\mathrm{CrCl}$ and $\mathrm{Cr}_{2} \mathrm{Cl}_{4}$.
We carried out a thermodynamic calculation of the interaction of chromium chlorides with the main component of steel - iron, which resulted in the formation of a solid solution between these two elements. The calculation was performed for two boundary compositions of the solid solution: $\left(\mathrm{Fe}_{0.9} \mathrm{Cr}_{0.1}\right)$ and $\left(\mathrm{Fe}_{0.1} \mathrm{Cr}_{0.9}\right)$, two temperatures and pressures. Below, in the table. Fig. 3 presents the results of calculating the interaction of chlorides with the surface of the steel, expressed as values of the occurrence of chemical reactions $\alpha$. Solid solution ss.

Table 3

The magnitude of the chemical reactions $\alpha$, describing the interaction of chromium chlorides with iron

\begin{tabular}{|l|l|c|c|c|c|}
\hline \multirow{2}{*}{ No. } & \multirow{2}{*}{ Chemical equation } & \multicolumn{3}{|c|}{ Process temperature, $\mathrm{K}$} \\
\cline { 3 - 6 } & & \multicolumn{2}{|c|}{1343} & \multicolumn{3}{c|}{1343} \\
\cline { 3 - 6 } & & \multicolumn{2}{|c|}{ Pressure, $\mathrm{Pa}$} & \multicolumn{2}{c|}{ Pressure, Pa } \\
\cline { 3 - 6 } & & 133 & 1.33 & 133 & 1.33 \\
\hline 1 & $\mathrm{CrCl}(\mathrm{g})+6.75 \mathrm{Cr}(\mathrm{s})=7.5\left(\mathrm{Fe}_{0.9} \mathrm{Cr}_{0.1}\right)(\mathrm{ss})+1 / 4 \mathrm{CrCl}_{4}(\mathrm{~g})$ & 0.985 & 0.23 & 0.975 & 0.043 \\
\hline 2 & $\mathrm{CrCl}(\mathrm{g})+6.75 \mathrm{Cr}(\mathrm{s})=7.5\left(\mathrm{Fe}_{0.1} \mathrm{Cr}_{0.9}\right)(\mathrm{ss})+1 / 4 \mathrm{CrCl}_{4}(\mathrm{~g})$ & 1 & 1 & 1 & 1 \\
\hline 3 & $\mathrm{CrCl}_{2}(\mathrm{~g})+4.5 \mathrm{Fe}(\mathrm{s})=5\left(\mathrm{Fe}_{0.9} \mathrm{Cr}_{0.1}\right)(\mathrm{ss})+1 / 2 \mathrm{CrCl}_{4}(\mathrm{~g})$ & $3 \cdot 10^{-6}$ & $3 \cdot 10^{-8}$ & $2 \cdot 10^{-6}$ & $2 \cdot 10^{-8}$ \\
\hline 4 & $\mathrm{CrCl}_{2}(\mathrm{~g})+1 / 18 \mathrm{Fe}(\mathrm{s})=5 / 9\left(\mathrm{Fe}_{0.1} \mathrm{Cr}_{0.9}\right)(\mathrm{ss})+1 / 2 \mathrm{CrCl}_{4}(\mathrm{~g})$ & $3 \cdot 10^{-6}$ & $3 \cdot 10^{-8}$ & $2 \cdot 10^{-6}$ & $2 \cdot 10^{-8}$ \\
\hline 5 & $\mathrm{Cr}_{2} \mathrm{Cl}_{4}(\mathrm{~g})+9 \mathrm{Fe}(\mathrm{s})=10\left(\mathrm{Fe}_{0.9} \mathrm{Cr}_{0.1}\right)(\mathrm{ss})+\mathrm{CrCl}_{4}(\mathrm{~g})$ & 0.014 & 0.014 & 0.016 & 0.016 \\
\hline 6 & $\mathrm{Cr}_{2} \mathrm{Cl}_{4}(\mathrm{~g})+1 / 9 \mathrm{Fe}(\mathrm{s})=10 / 9\left(\mathrm{Fe}_{0.1} \mathrm{Cr}_{0.9}\right)(\mathrm{ss})+\mathrm{CrCl}_{4}(\mathrm{~g})$ & 0.42 & 0.42 & 0.313 & 0.313 \\
\hline 7 & $\mathrm{CrCl}_{3}(\mathrm{~g})+2.25 \mathrm{Fe}(\mathrm{s})=2.5\left(\mathrm{Fe}_{0.9} \mathrm{Cr}_{0.1}\right)(\mathrm{ss})+1 / 4 \mathrm{CrCl}_{4}(\mathrm{~g})$ & $2.3 \cdot 10^{-6}$ & $5 \cdot 10^{-9}$ & $2.1 \cdot 10^{-6}$ & $5 \cdot 10^{-9}$ \\
\hline 6 & $\mathrm{CrCl}_{3}(\mathrm{~g})+0.0278 \mathrm{Fe}(\mathrm{s})=0.278\left(\mathrm{Fe}_{0.1} \mathrm{Cr}_{0.9}\right)\left(\mathrm{ss}^{-9}+3 / 4 \mathrm{CrCl}_{4}(\mathrm{~g})\right.$ & $2.3 \cdot 10^{-6}$ & $5 \cdot 10^{-9}$ & $2.1 \cdot 10^{-6}$ & $4.4 \cdot 10^{-9}$ \\
\hline
\end{tabular}

From the table 3 it follows that the formation of a solid solution consisting of iron and chromium occurs in accordance with reactions $1,2,5$, and 6 . In addition, usually there is an interaction of chromium vapor with the surface of the steel, which leads to the formation of a diffusion layer containing chromium. But the vapor pressure of metallic chromium is usually 1 to 2 orders of magnitude lower than the pressure of its chlorides, so its main carriers of chromium to the work surface are its chlorides. The transition of carbon into the compound leads to the formation of the component $\delta$-FeCr. The ratio of phases - carbide $\mathrm{Cr}_{23} \mathrm{C}_{6}$ and $\delta$-FeCr will determine the wear resistance and heat resistance of the steel surface. Changing the ratio of these phases can be done by varying the temperature and pressure in the reaction region, the temperature of chromium plating and the flow of sodium chloride. The particle size of chromium, the concentration of activator affect the pressure in the reaction space. 


\section{METAL ANALYSIS OF THE SURFACE OF CHROME SAMPLES}

In Fig. 1,a presents sample No. 6 after chromium plating at a temperature of $1070{ }^{\circ} \mathrm{C}$ for $8 \mathrm{~h}$. The total coating thickness is $71 \mu \mathrm{m}$. The upper layer of the diffusion layer consists of chromium carbide and has a high microhardness. The microhardness data presented, measured deep into the sample, show a sharp decrease in the values of this quantity (Fig. 2). Moreover, the microhardness decreases to a value less than the surface of the samples.

The microstructure of sample No. 7 is shown in Fig. 1,b. This sample was subjected to chemical-thermal treatment at a temperature of $1070{ }^{\circ} \mathrm{C}$ for $10 \mathrm{~h}$. After this treatment, the surface of the sample has a micro- hardness of $1270 \mathrm{~kg} / \mathrm{mm}^{2}$ and it decreases with increasing depth of measurement (see Fig. 2). Apparently, with an increase in the annealing time, a diffusion redistribution of carbon occurs in the surface region of the sample and this element is concentrated in the zone in contact with the saturating medium. Beyond the zone of chromium carbide is the region of the $\delta$ - $\mathrm{FeCr}$ component, which has a significantly lower microhardness. In Fig. 3 shows microsections of samples after chromium plating at a temperature of $1100{ }^{\circ} \mathrm{C}$. The structure of the sample after annealing for $6 \mathrm{~h}$ is shown in Fig. 3,a. The measured microhardness value (Fig. 4) in this case is not so high as in Fig. 2.
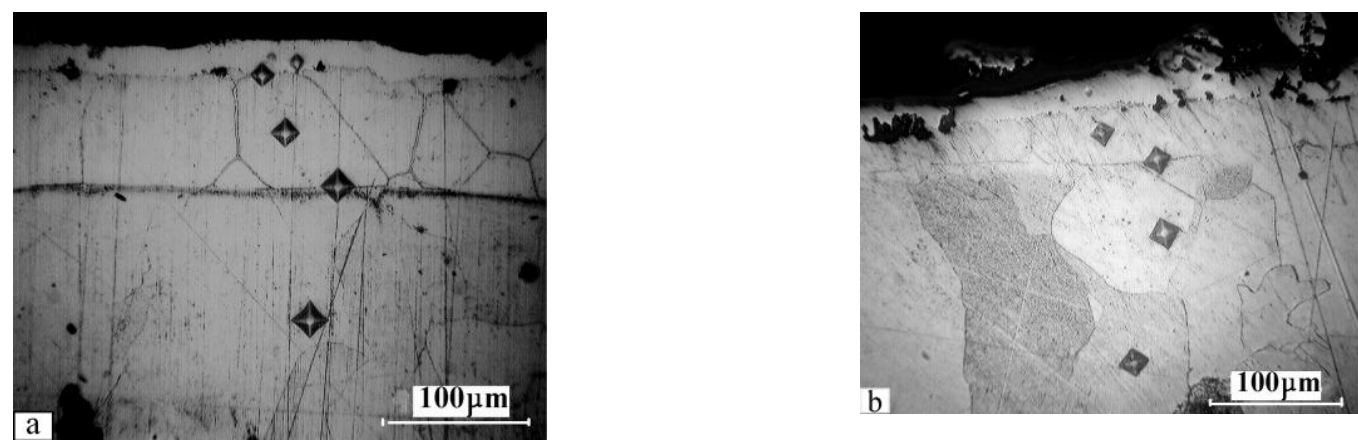

Fig. 1. Photos of samples: a-sample No. 6: coating thickness $(h, \mu m): 10,61$.

Coating Composition: $\mathrm{Cr}_{23} \mathrm{C}_{6}$ and $\delta$ - $\mathrm{FeCr}$;

$b$-sample No. 7: coating thickness $(h, \mu m): 40,50,1$.

Coating Composition: $\mathrm{Cr}_{23} \mathrm{C}_{6}$ and $\delta$ - $\mathrm{FeCr}$

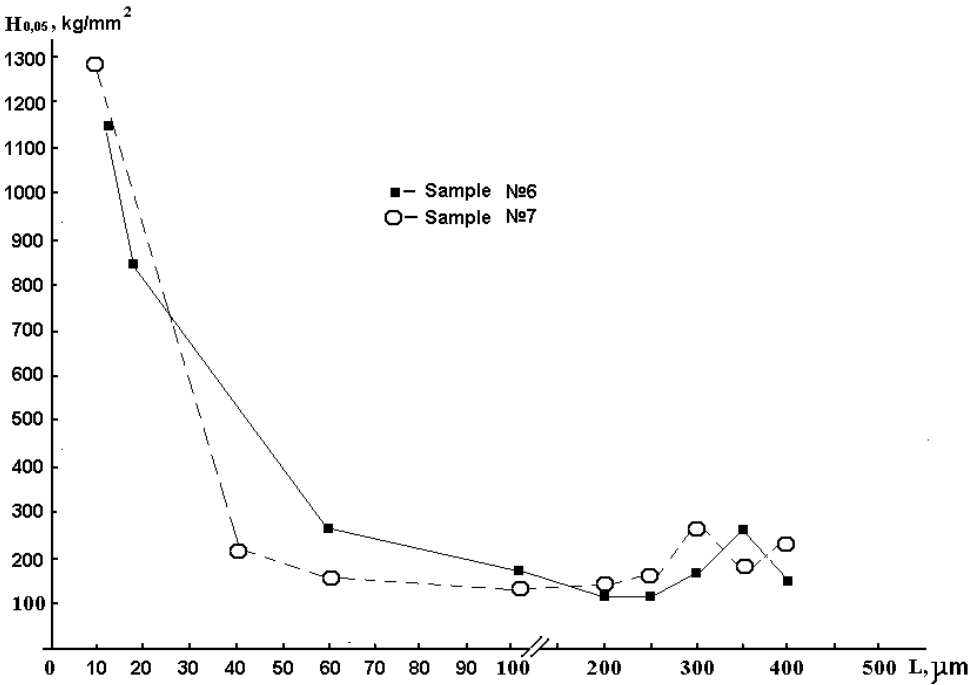

Fig. 2. Dependence of the microhardness of samples No. 6 and No. 7 along the depth of the sample

This is explained by a lower annealing temperature during chromium plating and, correspondingly, lower diffusion activity in the solid phase. The sample shown in Fig. 3,b, was subjected to longer exposure during chromeding $-12 \mathrm{~h}$. As a result of this, there was a greater redistribution of carbon in the surface region of the sample, a higher concentration of this element in this zone. This contributed to a higher value of microhardness.

Fig. 4 shows the change in the microhardness along the depth of the sample. Its change is not monotonous, but is somewhat wavy in nature. 

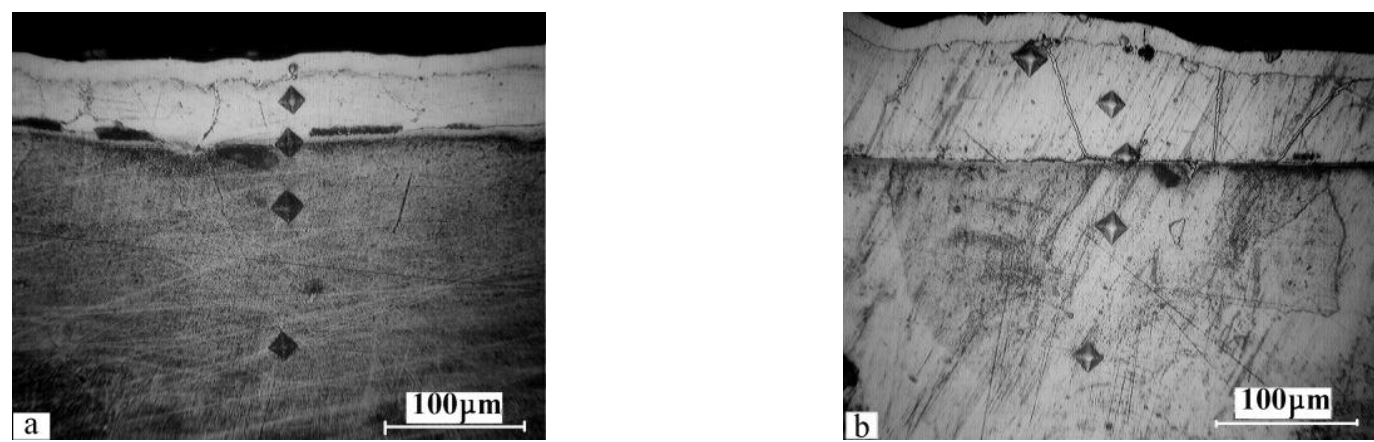

Fig. 3. Photos of samples: a-sample No. 1: coating thickness $(h, \mu m): 15,38,3$.

Coating Composition: $\mathrm{Cr}_{23} \mathrm{C}_{6}$ and $\delta$ - $\mathrm{FeCr}$.

$b$-sample No. 4. Coating thickness $(h, \mu m):$ 30, 90, 6. Coating Composition: $\mathrm{Cr}_{23} \mathrm{C}_{6}$ and $\delta$ - $\mathrm{FeCr}$

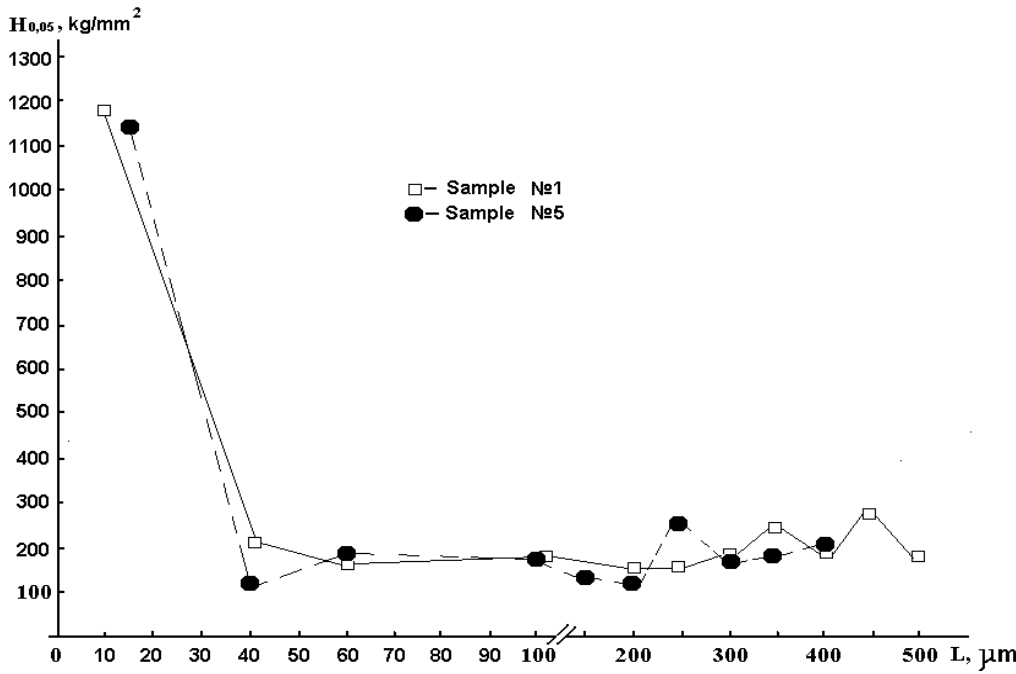

Fig. 4. Dependence of the microhardness of samples No. 1 and No. 4 over the depth of the sample

Table 4

Cavitation-erosive wear of the surface of samples of steel $25 \mathrm{X} 1 \mathrm{MF}$ in water and mechanical wear of these samples

\begin{tabular}{|c|c|c|c|c|c|c|}
\hline \multirow[b]{2}{*}{$\begin{array}{c}\text { No. } \\
\text { sample }\end{array}$} & \multicolumn{2}{|c|}{ Processing mode } & \multirow[b]{2}{*}{$\begin{array}{c}\text { Maximum micro- } \\
\text { hardness } H_{\mu} \text { of } \\
\text { diffusion layer, } \\
\mathrm{kg} / \mathrm{mm}^{2}\end{array}$} & \multirow[b]{2}{*}{$\begin{array}{l}\text { The total thick- } \\
\text { ness of the dif- } \\
\text { fusion layer, } \\
\text { microns }\end{array}$} & \multirow[b]{2}{*}{$\begin{array}{l}\text { Steady speed } \\
\text { abrasive } \\
\text { destruction } \mathrm{v}, \\
\mathrm{mg} / \mathrm{km}\end{array}$} & \multirow{2}{*}{$\begin{array}{c}\text { Loss of } \\
\text { sample mass } \\
\text { in } 3.5 \mathrm{~h} \text { of } \\
\text { erosion in } \\
\text { water, mg }\end{array}$} \\
\hline & $\begin{array}{l}\text { Temperature } \\
\text { chromium } \\
\text { plating, }{ }^{0} \mathrm{C}\end{array}$ & $\begin{array}{c}\text { Time } \\
\text { chrome } \\
\text { plating, h }\end{array}$ & & & & \\
\hline initial & - & - & - & - & 1.83 & 3.16 \\
\hline 1 & 1100 & 6 & 1072 & 56 & 0.56 & 1.46 \\
\hline 2 & 1100 & 8 & 787 & 86 & 0.95 & 2.13 \\
\hline 3 & 1100 & 10 & 1225 & 106 & 0.62 & 3.46 \\
\hline 4 & 1100 & 12 & 787 & 126 & 1.01 & 3.14 \\
\hline 5 & 1070 & 6 & 1144 & 54 & 0.74 & 2.81 \\
\hline 6 & 1070 & 8 & 1144 & 71 & 0.66 & 1.99 \\
\hline 7 & 1070 & 10 & 1270 & 91 & 0.94 & 3.28 \\
\hline
\end{tabular}

From the Table 4 it follows that all chrome-plated samples in terms of abrasion resistance exceed the starting material by 1.8 to 3 times. This is probably to be expected, because after chromium plating of steel samples, a protective layer of carbide of this element was formed on their surface. Chrome plating also mainly increases the resistance of the samples, protecting them from cavitation-erosion effects. Based on the data presented in Table 4, we can draw certain conclusions. The change in the thickness of the diffusion layer and its microhardness is not monotonic from the temperature of the process and its duration. This means that it is necessary to more specifically establish the relationship be- tween the process parameters and the change in the resistance of the samples with respect to mechanical stress and cavitation-erosion wear on the surface of $25 \mathrm{X} 1 \mathrm{MF}$ steel.

\section{CONCLUSIONS}

1. Vacuum activated diffusion chromium plating of samples made of $25 \mathrm{X} 1 \mathrm{MF}$ steel leads to the formation of a surface layer containing from 87 to $97 \mathrm{wt} . \%$ of this element. It was found that an increase in the temperature of the process and its duration leads to an increase in the chromium content on the surface of the samples. 
2. It was found that chromium plating increases the roughness of the samples. To eliminate this phenomenon, it is necessary to carry out studies to optimize the parameters of the chromium plating process.

3. Using thermodynamic analysis, it was found that the main chromium transporters in a saturating gas medium are, presumably, the lower chlorides of this element $-\mathrm{CrCl}$ and $\mathrm{Cr}_{2} \mathrm{Cl}_{4}$.

4. The maximum microhardness of the diffusion layer reaches $1270 \mathrm{~kg} / \mathrm{mm}^{2}$ and the thickness exceeds $100 \mu \mathrm{m}$. This coating consists of an outer layer of carbide of the composition $\mathrm{Cr}_{23} \mathrm{C}_{6}$ and a layer of a solid solution of chromium in iron located below it $-\delta$-FeCr.

5. The tests carried out on cavitation-erosion effects in water on the chrome-plated surface of $25 \mathrm{Kh} 1 \mathrm{MF}$ steel samples showed that chemical-thermal treatment mainly strengthens the steel surface.

6. It has been established that vacuum diffusion chromium plating of samples made of $25 \mathrm{X} 1 \mathrm{MF}$ steel provides 1.8-3 times higher resistance to abrasive when compared to the starting material.

\section{REFERENCES}

1. G.H. Meier, C. Cheng, et al. Diffusion Chromizing of Ferrous Alloys // Surface and Coatings Technology. 1989, v. 39/40, p. 53-64.

2. Jyh-Wei Lee, Jenq-Gong Duh. Evaluation of microstructures and mechanical properties of chromized steels with different carbon contents // Surface and Coatings Technology. 2004, v. 177-178, p. 525-531.

3. V.I. Zmij, G.M. Kartmazov, S.G. Rudenkyi. Patent for an invention No98074, C23P 8/00, C23P 12/00.
Method of diffusion saturation of the surface of the product, Publication date 10.04.2012, bull. No 7 (in Ukrainian).

4. V.I. Zmij, G.M. Kartmazov, S.G. Rudenkyi. Patent for an invention No98087, C23P 8/00, C23P 12/00. Device for diffusion saturation of product surfaces in vacuum, Publication date 10.04.2012, bull. No 7 (in Ukrainian).

5. V.I. Zmij, N.F. Kartsev, N.V.Kovtun, S.G. Rudenkyi. Study of the formation processes and properties of chromium-containing diffusion coatings on steels // Proceedings of the 4th International Symposium "Vacuum Technologies and Equipment”, Kharkov, April 2327, 2001, p. 266-268.

6. V.I. Zmij, S.G.Rudenkyi. Reaction-activated diffusion and vacuum coatings. Kharkov: NSC KIPT, 2010, $158 \mathrm{p}$.

7. S.G. Rudenkyi. Vacuum-activated chromium plating of steel 20 in nanocrystalline powder // Physical surface engineering. 2012, v. 10, N 1, p. 29-35.

8. S.G. Rudenkyi. Physical-technological fundamentals of the method of activated vacuum formation of multifunctional coating on metal and carbon materials: Doctoral dissertation. Kharkov: "Institute of Electrophysics and Radiation Technologies", 2014.

9. O. Kubashevsky, S.B. Olcoccus. Metallurgical thermochemistry / Edited by L.A. Schwartzman. M.: "Metallurgy", 1982, 392 p.

Article received 27.02.2020

\section{ВЛИЯНИЕ ВАКУУМНОГО АКТИВИРОВАННОГО ДИФФУЗИОННОГО ХРОМИРОВАНИЯ НА МЕХАНИЧЕСКИЕ СВОЙСТВА ПОВЕРХНОСТИ СТАЛИ 25Х1МФ

\author{
С.Г. Руденький, В.И. Змий, Н.Ф. Карцев, А.А. Корнеев, А.В. Кунченко, В.В. Кунченко, Ю.В. Кунченко,
} В.Г. Маринин, В.И. Коваленко, М.А. Бортницкая, Т.П. Рыжова, И.А. Ляиенко}

Проведено насыщение поверхности образцов из стали 25Х1МФ хромом. Для этого использовали метод вакуумного активированного диффузионного хромирования. В этом процессе в качестве активатора использовали хлористый натрий. Было установлено, что вакуумное активированное диффузионное хромирование образцов из стали 25Х1МФ приводит к формированию поверхностного слоя, содержащего от 87 до 97 вес.\% этого элемента. При этом установлено, что повышение температуры процесса и его длительности приводит к увеличению содержания хрома на поверхности образцов. Проведенные испытания показали, что в случае кавитационно-эрозионного воздействия на поверхность хромированных образцов из стали $25 \mathrm{X} 1 \mathrm{MФ} \mathrm{они}$ имеют более высокую стойкость. При абразивном износе стойкость хромированной поверхности стали в 1,8-3 раза выше по сравнению с необработанным материалом.

\section{ВПЛИВ ВАКУУМНОГО АКТИВОВАНОГО ДИФУЗІЙНОГО ХРОМУВАННЯ НА МЕХАНІЧНІ ВЛАСТИВОСТІ ПОВЕРХНІ СТАЛИ 25Х1МФ}

\section{С.Г. Руденький, В.І. Змій, М.Ф. Карцев, О.О. Корнєєв, О.В. Кунченко, В.В. Кунченко, Ю.В. Кунченко, В.Г. Маринін, В.І. Коваленко, М.О. Бортницька, Т.П. Рижова, І.А. Ляшенко}

Проведено насичення поверхні зразків зі сталі 25Х1МФ хромом. Для цього використовували метод вакуумного активованого дифузійного хромування. У цьому процесі в якості активатора використовували хлористий натрій. Було встановлено, що вакуумне активоване дифузійне хромування зразків зі сталі $25 \mathrm{X} 1 \mathrm{MФ}$ призводить до формування поверхневого шару, що містить від 87 до 97 мас.\% цього елемента. При цьому встановлено, що підвищення температури процесу і його тривалості призводить до збільшення вмісту хрому на поверхні зразків. Проведені випробування показали, що в разі кавітаційно-ерозійного впливу на поверхню хромованих зразків зі сталі 25Х1МФ вони мають більш високу стійкість. При абразивному зносі стійкість хромованої поверхні сталі в 1,8-3 рази вище в порівнянні з необробленим матеріалом. 